Instructions for authors, subscriptions and further details:

http://qre.hipatiapress.com

\title{
The Impact of Environmental Education Activities on Primary School Students' Environmental Awareness and Visual Expressions
}

Mustafa Yeşilyurt $^{1}$, Mukadder Özdemir Balakoğlu ${ }^{1}$ \& Mustafa Erol ${ }^{1}$

1) Yildiz Technical University, Faculty of Education, Department of Basic Education, Primary School Education, Istanbul, Turkey

Date of publication: June $28^{\text {th }}, 2020$

Edition period: June 2020 - October 2020

To cite this article: Yeşilyurt, M., Özdemir Balakoğlu, M., \& Erol, M. (2020). The Impact of Environmental Education Activities on Primary School Students' Environmental Awareness and Visual Expressions. Qualitative Research in Education, 9(2), 188-216. doi:10.17583/qre.2020.5115

To link this article: $h t t p: / / d x . d o i . o r g / 10.17583 / q r e .2020 .5115$

\section{PLEASE SCROLL DOWN FOR ARTICLE}

The terms and conditions of use are related to the Open Journal System and to Creative Commons Attribution License (CC-BY). 


\section{The Impact of Environmental Education Activities on Primary School Students' Environmental Awareness and Visual Expressions}

Mustafa Yeşilyurt

Yildiz Technical University

Mustafa Erol

Yildiz Technical University

(Received: 29 January 2020; Accepted: 19 June 2020; Published: 28 June 2020)

\section{Abstract}

The aim of this research is to improve environmental awareness in primary school students. For this purpose, the study was carried out within the scope of action research pattern from qualitative research patterns. The study group was determined by selecting easily accessible samples. The study group consisted of second year students attending a state primary school in Gungoren District of Istanbul in the 2018-2019 academic year. The data of the study were obtained by the students' environmental pictures, observation forms and semi-structured interview forms. The data obtained were analyzed by content analysis. According to the findings of the research, it is determined that students who received environmental education, draw pictures enthusiastically and reflecting environmental awareness, also after interviews students gain awareness toward environment, empathized with nature and draw highly esthetically appreciated pictures.

Keywords: environmental awareness, primary school students, visual expression, empathy 


\section{EI Impacto de las Actividades de}

Educación Ambiental en la Conciencia

\section{Ambiental y las Expresiones Visuales de los Estudiantes de Primaria}

Mustafa Yeşilyurt

Yildiz Technical University

Mustafa Erol

Yildiz Technical University

\author{
Mukadder Ozdemir Balakoğlu \\ Yildiz Technical University
}

(Recibido: 29 de enero de 2020; Aceptado: 19 de junio de 2020; Publicado: 28 de junio de 2020)

\section{Resumen}

El objetivo de esta investigación es mejorar la conciencia ambiental en los estudiantes de primaria. Para este propósito, el estudio se realizó dentro del alcance del patrón de investigación-acción a partir de patrones de investigación cualitativa. El grupo de estudio se determinó seleccionando muestras de fácil acceso y consistió en estudiantes de segundo año que asistieron a una escuela primaria estatal en el distrito Gungoren de Estambul en el año académico 2018-2019. Los datos del estudio fueron obtenidos por las imágenes ambientales, los formularios de observación y los formularios de entrevista semiestructurados de los estudiantes. Los datos obtenidos fueron analizados por análisis de contenido. De acuerdo con los resultados de la investigación, se determina que los estudiantes que recibieron educación ambiental, hacen dibujos con entusiasmo y reflejan la conciencia ambiental, también después de las entrevistas, los estudiantes adquieren conciencia hacia el medio ambiente, empatizan con la naturaleza y dibujan imágenes muy apreciadas estéticamente.

Palabras clave: conciencia ambiental, estudiantes de primaria, expresión visual, empatía 
$\mathrm{T}$

he history of life on Earth is actually the history of living things interaction with their environment (Carson, 2011). Human beings in a constant interaction with other living and inanimate beings in historical context are an element of the environment but both affect the environment and are affected by the environment. Because, human is constantly within the environment. While the effects of the environment on human are generally positive (Van Den Berg et al., 2015) the effects of human on the environment have recently started to be negative. In short, the main factor of environmental problems is becoming human. Therefore, we can use education as a process of changing individuals, gaining the desired behavior, thought, value judgment, knowledge and skills in the individual in the solution of environmental problems. Environmental education is a learning process that aims to gain behaviors in individuals by including information, awareness, awareness raising, stimulation, balancing, development, protection (Güler, 2009; Vaughan et al., 2003).

Educating individuals who are aware of environmental problems and can deal with these problems is one of the main aims of environmental education (Xuehua, 2004; Waktola, 2009). In addition, another aim of environmental education can be expressed as giving individuals environmental attitudes, environmental friendly behaviors, skills needed for protecting, improving and improving the environment (Nagra, 2010) and gaining environmental awareness. The main purpose of environmental education is the effort to protect and maintain the existence of biodiversity (Broyles, 2011; Damerell, 2007; Wells \& Zeece, 2007). Individuals with environmental awareness, or who are aware of the impact of environmental problems on society and themselves, are expected to act with regard to the environment in each of their activities while continuing their lives (Gadenne et al., 2009).

Attitudes, values and behaviors towards protecting, beautifying and improving the environment express the concept of environmental sensitivity (Long, 2007). Individuals can gains that one could live in harmony with nature and the natural balance concept, develop positive attitudes and values towards the environment, and gain the behaviors required for the solution of environmental problems related with an effective environmental education (Erol \& Gezer, 2006; Milton et al., 1995). In this respect, the people who can not harm the environment, develop, protect, beautify and reshape need to receive a quality education (Öznacar et al., 2010). 
Nature education teaches children skills such as humility and empathy (Louv, 2012). In another perspective, nature heals children's emotional wounds (Louv, 2012) and increases their creativity. Environmental education can be accepted as science education since it is an interdisciplinary education, learning-by-living-based, supporting problem-solving skills and helping children to gain experience and requiring the active participation (Sugg, 2008).

\section{Relationship between Visual Perception, Environment and Learning}

The senses are the starting points that affect the formation of our emotions. Some basic learning takes place in the world of the senses. The individual remembers and does not forget its color, smell, sensory perception characteristics before recognizing or learning something. In art education, doing wrong is a learning method, and the gains in artistic learning come from the individual's actions and choices. Artistic production is also often the expression of the senses, and man's perception of himself is closely related to what objects reflect upon him. Perception is the process of organization and interpretation of stimulus images in the environment. The process of visual perception, according to Gal and Linchevski (2010), is considered to be the process of perception and processing of visual information from sensory and mental processes. The goal in visual perception education is to enable individuals to focus on the entity qualities of an object (Artut, 2009). In this respect, the development of perception about the environment is important for every individual at every moment of life. The individual gains their experience and experience of life and the universe in the process of perceiving their environment and events. If the human mind does not have the right templates for the environment, reason and thought are incapable of achieving the right function and the environment is threatened by human behavior (Krishnamurti, 2008). Since the state we call awareness is to perceive our relationship with things outside of us, the path to it is expected to go not through verbal and mental perception, but through visual perception and perception of beings.

Sensory perceptions are types of learning that are understood by the observation of the individual and their measurement varies according to each individual. But learning in the totality of life is not provided by mind 
operation and intellect alone. There are also effective forms of learning provided by the senses, and most of our learning takes place through sensory perceptions. Our sensory perceptions also play an important role in our relationship and interaction with the objects around us. Our perceptions are not only sensory, but also emotional. Because people also add emotion to all the objects they perceive, even everything. It's hard to find objects free of emotion in our lives. Here, the emotional quality derives not from the object itself, but rather from the individual who gives the object these qualities. Sometimes it takes it from the object, from the environment, sometimes from the individual.

The educational activities that individuals actively participate enable the individual to learn effectively and permanently through their learning lives. In addition to these gains, active participation activities reveal the creative side of the individual and create a suitable environment for the development of original opinions and thoughts. For these gains to occur, students need to be intertwined not only with their classroom settings but also with their surroundings. Because the wealth of stimulants has an important role to play in children's learning. The most appropriate way to provide an education that takes place through sensory perceptions is to establish strong connections between activities and the subject (learning together, learning experience). This is an attitude that cares about the individual, not only the student's knowledge, but also his or her liking, contribution, seeing, sensory perception, discoveries and all sensations. In addition, while the types of learning gained through mind perceptions enhance our intelligence, environmental perceptions improve our awareness, sensory perception, vision, artistic direction and personality.

\section{Importance of the Study}

In the learning process, the teacher must ensure that students participate in one-to-one activities for effective learning. Today, educators state that students are in the position of information producer and that students should take an active role in the education process. When the relevant literature is examined, it is observed that researches related to environmental awareness and sensitivity are carried out (Danielraja, 2019; Egbonyi \& Onnoghen, 2016; Hadzigeorgiou \& Skoumios, 2013; Rogayan \& Nebrida, 2019; 
Wihardjo et al., 2017). In addition, it has been determined that the sensitivity and awareness of the students taking environmental education in the related field have increased (Yener \& Kalipci, 2007). Özsoy and Ahi (2014) wanted to reveal the future-oriented environmental perceptions of Primary School students through the pictures they drew, and as a result of the pictures drawn, it was determined that the students' awareness of the living-inanimate elements in the environment was limited. It is thought that the students 'environmental awareness will improve, the students' environmental sensitivity will increase, and the students will become individuals with environmental awareness by empathizing with nature.

\section{Purpose of the Study}

The aim of the research is to determine the impact of environmental education activities applied to primary school students on the students' environmental awareness. For this purpose, the sub-problems that are answered in the research are stated below.

What is the impact of environmental practices supported by environmental activities on students' environmental awareness and sensitivity? What is the impact of environmental practices supported by environmental activities on students visual expression abilities? What are the student views on environmental practices supported by environmental activities?

\section{Method}

\section{Model of Research}

Action research describes the work performed by a practitioner who is personally involved in the application, either directly with himself or with a researcher. Action research (Seggie \& Bayyurt, 2015; Yildirim \& Simsek, 2016) involves collecting and analyzing systematic data aimed at raising questions about the implementation process or understanding and solving an uncovered problem. When the relevant field literature is examined, it is seen that action research is classified in different ways. This study was conducted with applied action research from action research types. 


\section{The Research Working Group}

The participants of this study were 38 students who attended the second grade of a primary school in Esenler district, Istanbul Province, and were selected by an easily accessible sample. The easily accessible sampling method can be utilized to minimize time, labor, and cost loss, adding speed and practicality to research (Patton, 2015; Yildirim \& Simsek, 2016). 2/D class students participated in the research. The study group was determined as the number of students in the class.

\section{Working Environment}

The study was conducted with the participation of researchers. The school is a primary school in Esenler district of Istanbul. The estimated number of students in the classes at the school ranges from 30-40. The class included in the study has 38 students. The school in which the students in the study group study is at a moderate socio-economic level.

\section{Data Collection Tools}

\section{Personal form}

The personal data form was prepared by the researchers in order to know better the participants of the study and to analyze the factors that may have an impact on the research. In the personal data form, subjects such as the sexes and ages were examined to get to know the sample group closely. In Table1 below, information about the demographic variables of the participants is given. 
Table 1

Demographic Variables Related to Participation

\begin{tabular}{llllllll}
\hline \multirow{2}{*}{$\begin{array}{l}\text { Demographic } \\
\text { Variables }\end{array}$} & \multicolumn{3}{c}{ Total } & Demographic & \multicolumn{2}{c}{ Total } \\
\cline { 3 - 4 } & & f & $\boldsymbol{\%}$ & Variables & & f & $\%$ \\
\hline \multirow{3}{*}{ Gender } & Girl & 20 & 52.6 & & 7 y old & 24 & 63.1 \\
& Boy & 18 & 47.4 & Age & 8 y old & 14 & 36.9 \\
& Total & 38 & 100 & & Total & 38 & 100 \\
\hline
\end{tabular}

\section{Pictures}

Includes pictures made by students in order to determine students' perceptions about the environment. Images were used to determine the students' perceptions of the environment and to examine the students' ability to reflect the environment in visual language.

\section{Semi-structured interview forms}

Semi-structured interview forms based on environmental awareness were used to better understand and interpret student images in the research. The most powerful feature of interviews in qualitative research is that they provide the opportunity to learn about what we do not see and to make alternative explanations about what we see (Glesne, 2013). In this direction, interviewing is necessary to learn what we cannot directly observe, behaviors, situations, emotions, or how people express the world around them (Merriam, 2014; Patton, 2015). Semi-structured interviews with the help of open-ended questions allow the participant to describe the perceived world with their own thoughts (Merriam, 2014). Interview questions were asked some of which qualified as probes, in accordance with the flow of research to increase the wealth of data and deepen participants' views. Probes can be arranged to ask more questions about details, ask them to explain, or take samples (Merriam, 2014). In addition, at some stages of the interview, the data quality of the research was improved with questions such as why and wherefore to fully reflect the experience. The interviews were conducted oneon-one in the appropriate settings of the participants. The data obtained 
through one-to-one interviews were recorded with the help of a voice recorder.

\section{Observation forms}

It's forms prepared by researchers to record parts of students' conversations and the notes that written by researchers related to students' practices during activities. Observation is a research technique to gain knowledge about the events that occur there by observing people in their natural environment (Güler et al., 2014). Since the most important feature of observation is to provide first-hand access to data (Yildirim \& Simsek, 2016), it has been preferred to achieve data diversity and support other data in this research.

\section{Data Collection Process}

The data of the research was first obtained through the pictures made by the students. In the collection of data, students were asked to make pictures about the environment and the pictures made by the students were analyzed by the researchers. In order to better understand the data obtained from the images in the research and to provide a variety of data in the research, the semistructured interview technique, which is the data collection methods of qualitative research, has been utilized. In addition, observation forms were also used for data collection, semi-structured interview and detailing data from student pictures.

\section{Analysis of the Data}

In this study, data obtained through semi-structured interview, pictures and observation were analyzed by content analysis method. Content analysis is expressed as an important analysis method for analyzing and making sense of qualitative data by scanning qualitative text in line with repeating words and themes, and to determine the fundamental consistency of large volumes of qualitative material (Patton, 2015). In line with content analysis, coding was done first and themes were reached through these encodings. Coding can be defined as making symbolic abbreviations to various areas of the data, in order to obtain cross-sections from the data obtained in the study (Merriam, 
2014). Accordingly, coding was created in the form of small notes. Themes (categories) have also occurred with a combination of repeated encodings (Yildirim \& Simsek, 2016). Categories are defined as conceptual elements that contain, encompass, and interrelate multiple original examples (Merriam, 2014). In this respect, data analysis, data coding, coding themes were reached by using an inductive method and abstraction was made. In addition, the themes obtained as a result of the analysis processes were presented as titles in the findings section and supported by other study findings in the field paper.

\section{Validity and Reliability}

The conclusiveness of the results is considered one of the most important issues of scientific research (Yildirim \& Simsek, 2016). Validity in qualitative research is related to whether the findings of the research are correct. In this respect, valid and reliable research is the two most important issues. The following procedures were performed to ensure validity and reliability of the research.

- Volunteerism was sought in the students who participated in the research.

- Since validity in qualitative research is often related to the meanings and results extracted from the data (Güler et al., 2014) the research data was also checked by a different researcher and similar themes and categories were obtained.

- In order to understand the relevance of the questions in the prepared interview form, the first pre-application was made with 2 students and both the intelligibility of the questions was measured and the experience was obtained before the actual application.

\section{Role of Researchers}

Qualitative research is based on interpretation, and researchers are often in intense experience and continuity with participants (Creswell, 2017). In this study, researchers were directly involved in the data collection process and in the analysis of the data and undertook several tasks. In the data collection 
process and data analysis, researchers have taken care to be as objective as possible.

\section{Findings}

\section{Action Process and Operations}

Various objects (tulips, tree saplings, organic stationery sets, etc.) has been used for the development of environmental awareness in students and nature trips (Environmental Studies, Environmental Pollution Awareness trips, etc.) has been utilized. The objects used in the research and nature trips are briefly described below

Real objects: money, tools, plants, animals are easily accessible materials. Real objects are suitable for those who learn subjects where there is little to live directly from everyday life. These materials can be used as they are or modified to make teaching more effective. In addition to presenting information, asking questions and presenting a life of learning from the first source, real objects are also effective in evaluating teaching.

Nature trips: these trips are mostly carried out outside classrooms using real processes, people and objects. Nature trips are created due to the requirements of students' first-hand experience. The main attractions are zoos, museums, public buildings and parks.

\section{Status determination studies}

The study was conducted in a state primary school in Esenler district of Istanbul. The pictures drawn by 34 students were examined. Some examples of the paintings made by 24 of the students are shown in Figure-1. 

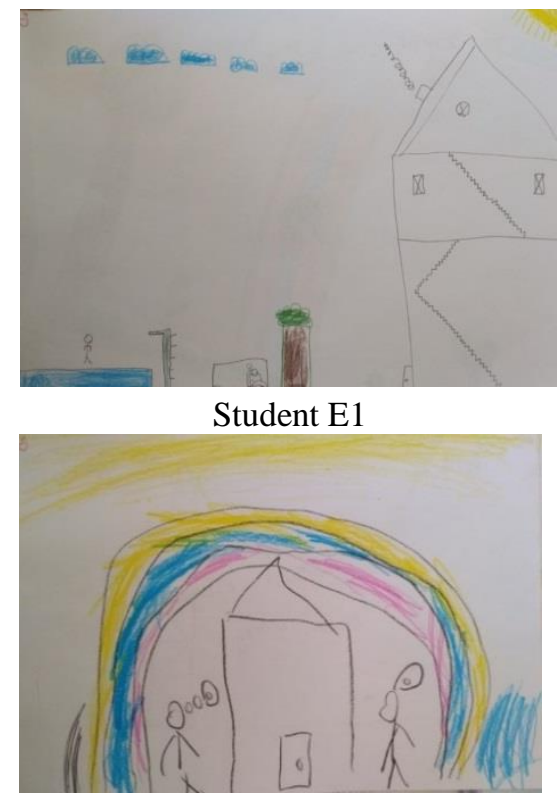

Student K2

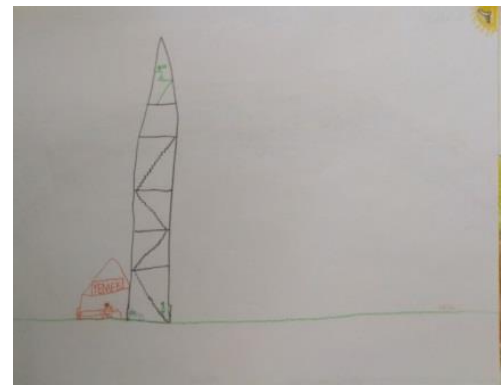

Student K1

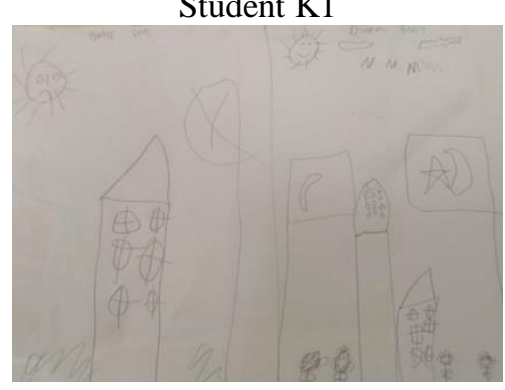

Student E2

Figure 1. Examples of Pictures Drawn by Students before the Action Plan is Implemented

When Figure 1 was examined, it was determined that the paintings lacked esthetic appreciation, did not reflect environmental awareness, had insufficient knowledge of environmental concepts and the students could not make enthusiastic paintings. Since it is thought that improving students' environmental awareness will reveal the aesthetic aspect of student paintings and make environmental awareness permanent, it has been decided to conduct Action Research.

\section{Preparation of the action plan}

In the preparation of the action plan, the necessary permissions were obtained from the parents of the students, the school administrator and the classroom teacher of the students and the students were asked if they wanted to participate in the study. Then, students were asked what they knew about the 
environment. What do you know about the environment? What kind of environment would you like to live in? What kind of environment do your paintings reflect? Do others like the pictures you've made? Want to make more beautiful pictures about the environment? Do you draw your dream environment? Similar questions were asked to determine the students' thoughts on the subject. The conversations with the students were recorded with a voice recorder and the data obtained was analyzed with content analysis. After the analysis of the data, it was determined that the students' knowledge about environmental concepts was insufficient. The importance of activities such as nature trips, tree planting activities were explained to the students and the subjects were integrated with the daily lives of the students. In addition, the activities are prepared in accordance with the age and development characteristics of the students. Because, the behaviors that will be acquired by the students in the artistic activities should be in accordance with the level of readiness of the students and it should be ensured that they make connections with the student's life during the education process (Artut, 2009). Then, the relevant literature was scanned, studies on environmental education were examined and it was determined that students should actively participate in the environment in increasing environmental awareness (Evans et al., 2007; Hungerford \& Volk, 1990).

Before starting to the research, plans were drawn up and the families of the students were informed about the activities to be carried out. The classroom was managed by the classroom mother, undergraduate students who took the environmental education course in the classroom, and a parent who was allowed to participate in the activities. Eight undergraduate students and one parent attended the applications. In addition, materials to be used by the students in the field were provided by the classroom teacher and researchers.

\section{Implementation of the action plan}

The action plan lasted approximately 120 minutes of sessions on two days of the week for a total of 6 weeks. A total of 12 sessions were held. In addition, trees were brought into the classroom and for three weeks students were provided to take care of trees outside of activities. In order to ensure the permanence of the activities, family participation activities were also 
prepared and families were asked to participate environmental trips with their children on weekends and talk about the environment. The activities with family participation were determined as 10 sessions in total. Parents of the entire working group participated in activities with family participation. Family involvement activities were generally carried out with the mother, and in some cases, fathers helped the activities. During the course of the activities, students were treated in accordance with their development characteristics and national educational attainment and the teaching process was staged as follows.

1. Parent informing studies and preparation of the plan

2. Presentations on developing environmental awareness

3. Nature trips

4. Tree gardening studies

5. Tree and tulip planting studies

6. Evaluation of gains studies 


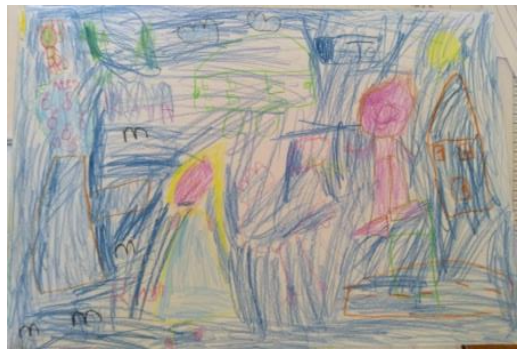

Student E4

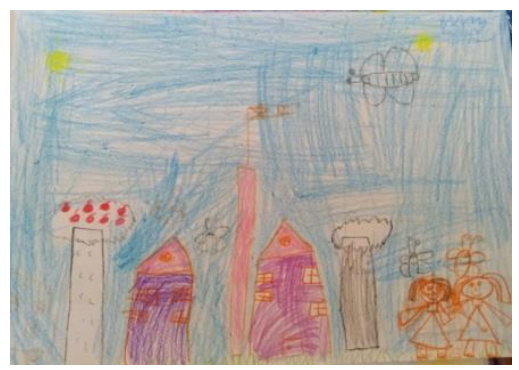

Student K3

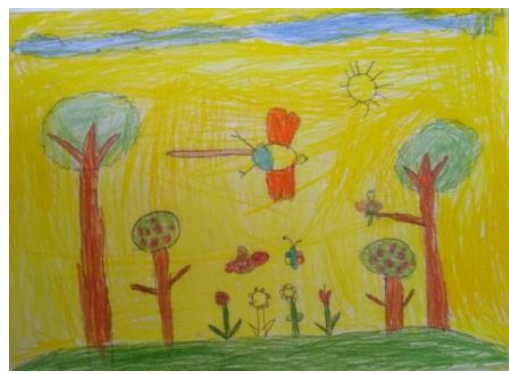

Student E5

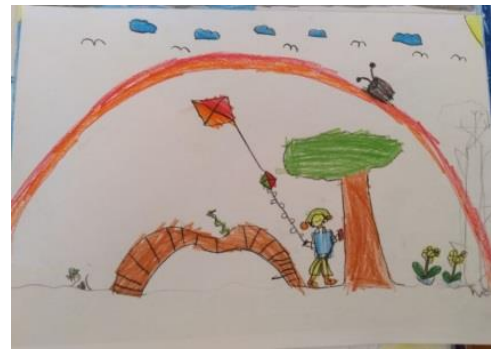

Student E3

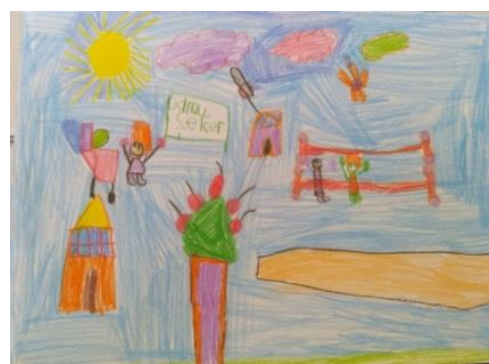

Student K4

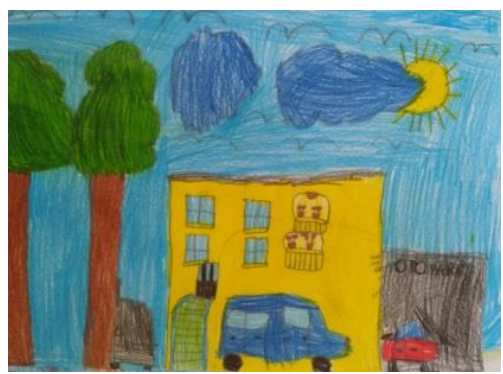

Student E6

Figure 2. Examples of Pictures Drawn By Students after the Action Plan Is Implemented

In Figure 2, examples of the pictures drawn by the students after the study are given. After the implementation of the action plan, it was determined that the students (the vast majority) gave details about the environment, gained the ability to use the entire paper, provided elements of the natural environment, made paintings with visual expression skills and high 
enthusiasm for esthetics. Environmental education given at an early age allows students to develop positive attitudes towards the environment later in life (Davis, 2009; Grodzinska-Jurczak et al., 2006; Walsh-Daneshmandi \& MacLachlan, 2006; Wilson, 1996). It has been observed that environmental activities carried out in this direction have positive repercussions on children's visual expression skills. It is seen that the activities increase the sensitivity to the environment and this is reflected in the visual expressions of the students.

\section{Evaluation of the effectiveness of the application}

It is seen that the pictures made by the students after the application reflect the environment more clearly. Especially when students paint with enthusiasm, aesthetic dimension of drawings, their visual expression skills and environmental awareness are evaluated, it is seen that the students have positive effects on their aestheticizing abilities, sensory perceptions and visual expressions. Examples of the students' first and last pictures showing the development of their visual expressions are given below in Figure-3. 


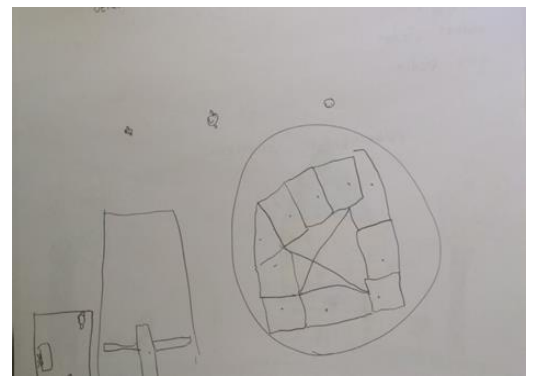

Before Application (Student M)

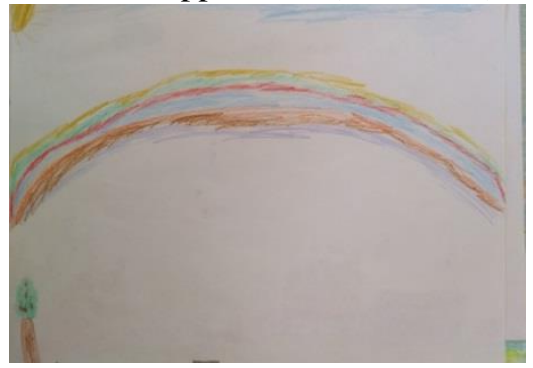

Before Application (Student K)

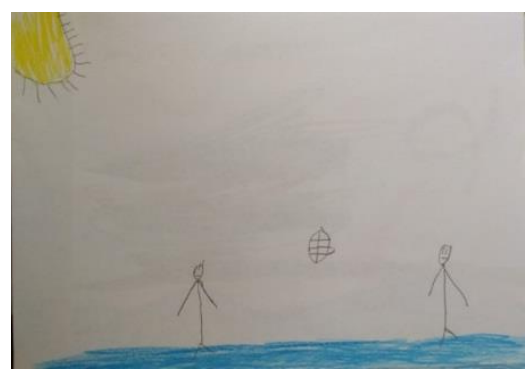

Before Application (Student E)

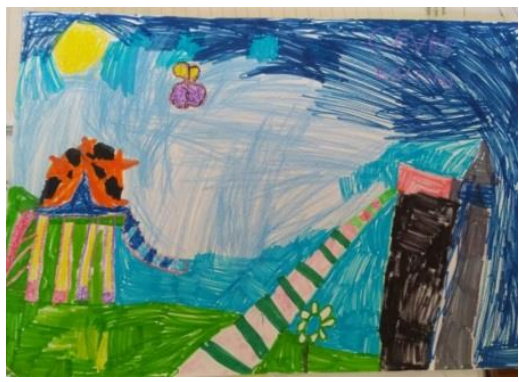

After Application (Student M)

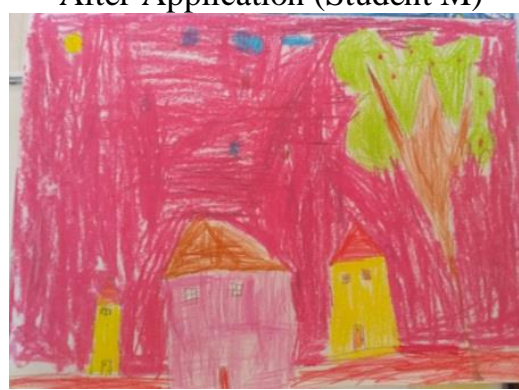

After Application (Student K)

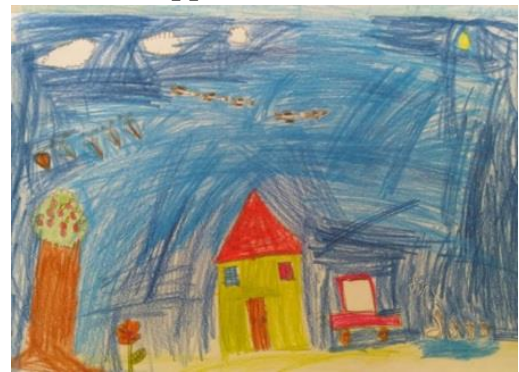

After Application (Student E)

Figure 3. Pictures of the Same Student before and After the Application

The pictures before and after implementing the action plan are given in Figure 3. The pictures given are two different pictures made by the same students. When the pictures drawn by students $\mathrm{M}, \mathrm{K}$ and $\mathrm{E}$ after the action plan has been implemented are examined, it is seen that environmental sensitivity has improved, they use the picture page fully, they have high aesthetic appreciation, visual expressiveness and they paint enthusiastically. 
Student interviews show that environmental education activities are effective in visual expression of the student.

I had a lot of fun in planting trees with these friends and my teacher and I wanted to show my joy in my pictures. (Student M)

When planting trees with my friends I saw that the sky was not only blue but also red. I wanted my picture to be pink, too. (Student K)

I'm an environmental detective, I warn people if they throw trash on the floor. I made this picture because there's an environment in it that I want to live in. If you love yourself, you must protect trees, forests and animals. (Student E)

When asked why the student painted more simply in the first picture, he said,

I had to do it because our teacher asked, but the places we went were so beautiful that I wanted to show it.

It was determined that the students gained environmental awareness by analyzing the qualitative data collected through interview and observation. The themes found after the analysis of the data are described below with oneto-one excerpts from student views.

\section{Theme-1: Gaining Environmental Awareness/Awareness}

Examples of student statements evaluated within this theme are as follows:

- Life can end immediately for a tree, with a spark...

- Lets hand in hand for a better world lets protect our environment

- Let's not damage the forests, let's not lose oxygen.

- Let us not forget that we drink milk through animals, eat meat, and eat fruit through trees".

- Think about how the trees will suffer if you hurt them once.

- Why do you mistreat trees and animals what they have done to you, except to help you. 
- Destroying forests is destroying ourselves.

- Extinguish the barbecue close before you leave, our forests are entrusted to us.

- Beautiful trees. Little flowers. This nature gives us little breaths.

- Destroying trees is destroying ourselves.

Almost all of the students who participated in the study stated that they developed environmental awareness and gained environmental awareness. The reason for this situation can be explained as follows. It is seen that the activities affect students' perceptions of the environment, from interviews and pictures drawn by the students since it is limited where students can play, interact and spend time in large cities such as Istanbul. The large playgrounds of children and their interaction with the environment in small settlements positively affect children's environmental awareness.

It has contributed to the development of environmental awareness in the participatory studies. Student K1 describes a family-attended activity as follows:

On Sunday, my family and I visited the environment. We sat on the grass. We smelled the flowers. We sat at under the tree and had our breakfast. We went around, got some nice air. Our day was very good

\section{Theme-2: Visual Language}

The following examples are given for the student statements that are evaluated in this context:

- I wanted to draw the environment in my first painting, but I couldn't. Then I discovered the environment and recognized that the environment was actually different.

- I planted trees for the first time in my life. I was so happy and I wanted to show it with the picture.

- I love drawing. I started to like it more after the trip.

- While I was drawing, I drew my dream environment. 
It was determined that the majority of the students who participated in the study used visual language more effectively in their paintings than in their first pictures. In order to better understand the subject, the students were interviewed on their pictures and it was determined that the students gained environmental awareness effectively. It was determined that the effect of the activities (trees, tulips, flowers, etc.) which planned as a learning experience in order to improve the environmental awareness and sensitivity of primary school students on their verbal and visual life, their interest in the environment and their visual expression and perceptions about the environment was positive.

\section{Theme-3: Building Empathy with Nature}

Examples of student statements evaluated within this theme are as follows:

- They love us, we love them. Imagine yourself as a tree. Would it hurt if they burned you?

- Don't set fire to the woods, don't burn them, they are alive like you.

- What the forests have done to you, why are you so selfish, don't always think of yourself please have some empathy.

- We all live together in this world and we need to understand each other.

- We need each other in this world.

- Being human requires understanding our environment.

Most of the students involved in the study empathized with nature and put it in nature's place themselves. This shows that the activities are internalized by the students. In addition, the interaction of the students with nature and learning by doing and living enabled the students to connect with nature and contributed to the students to develop an environment-centered perspective. According to life based or ecologically based philosophy, the one of the goals of environment education for students, to gain new psychological and moral norms and behaviors based in nature, by establishing empathy with the world and the nature of life to look, to teach the human-centered perspective instead 
of an eco-centric perspective. At this point, it can be said that environmental activities are effective in the students' ability to empathize with nature.

\section{Discussion and Conclusion}

The data were obtained from the images drawn by the students, interview questions and observation forms. Yavuzer (2012) stated that in the process of evaluating the pictures drawn by children, it is not right to make an inference based on the findings reached only through pictures, and that the findings reached must be supported by the findings reached by another method. At this point the data was supplemented by semi-structured interview forms and observation forms. Very different results obtained from the pictures students have drawn, it is determined that awareness raising process enhance students' environmental awareness and sensibilities, contribute their level of aesthetic appreciation, increase their self-confidence and they draw enthusiastically paintings and there is a positive impact on students' visual expression and perception. It was determined that some of the students did not show any improvement before and after the application. However, the majority showed positive developments in environmental awareness and esthetics. Shepardson (2005) states that students better perceive the environment in which they meet their requirements and interact. Because we are interacting with rivers, birds, trees, the extraordinary light of the evening, or the sunlight that hits the water, and if there is no interaction or connection between you and anything, you are a dead person (Krishnamurti, 2012). In addition, positive experiences of individuals in the external field are also effective in improving environmental sensitivity (Evans et al., 2007; Hungerford \& Volk, 1990).

Students were insufficient in their pre-application pictures since they were not familiar with the concepts of environment. When the relevant literature is examined, it was determined that the information about students' environmental concepts is insufficient, and they did not fully understand these concepts (Cutter-Mackenzie, 2009; Meinhold \& Markus, 2005; Mahidin \& Maulana, 2010; Said et al., 2002; Uzun et al., 2008). Accordingly, an action plan has been prepared to increase students' environmental awareness. Through the action process, it is aimed that students gain awareness of environmental concepts. In this process, environmental trips, 
tree planting studies, planting tulip studies, maintenance of trees, etc. has been done. Just watching nature gives students many gains. Because in this watching there is learning, maybe you haven't focused on something, you don't watch anything, but even in this nothingness there is everything (Krishnamurti, 2012).

It was thought that the use of artistic expression for environmental awareness would foster interest (Özdemir Balakoglu, 2019), as human's fondness for beauty makes it imperative to see and perceive. The activities provided a strengthening and feeding of visual perception in the students. In order for an aesthetic situation to arise, the subject must interact with the object. It is our view that aestheticizes objects in any case. There is no selfaesthetic or self-aestheticized object. In the study, it was determined that there were significant differences in environmental awareness among the students' pictures after the applications. It can be said that this affects students' attitudes towards the environment and is effective in improving students' visual perceptions. Because environmental education imparts knowledge and experience to individuals by changing individuals beliefs, attitudes and most importantly, their behavior (Frantz \& Mayer, 2014).

As a result of the activities, students stated that environmental problems are harms to society (Student, $\mathrm{K}$ "when we cut down trees it will become impossible to get oxygen"). Individuals with environmental awareness, or who are aware of the impact of environmental problems on society and themselves, are expected to act with regard to the environment in each of their activities while continuing their lives (Gadenne et al., 2009). It was also determined that the students could establish a cause-and-effect relationship with the environment (Student, A "destroying forests is destroying ourselves").

Research shows that families do not have enough awareness to inform their children about the environment (Simsekli, 2004). In this research, families were included in the activities in order to ensure the sustainability of the environmental awareness gained by the students. Family participation activities (some of the activities are activities that require family participation and activity) in the study were also found to be effective in improving students' environmental awareness.

According to another finding of the study, it was determined that the activities were effective in the development of students' skills to empathize 
with nature. Louv (2012) stated that in order for children to learn effectively basic knowledge about trees, birds and nature, a foundation of empathy must be established in students. When the field is examined, it is stated that interacting with the environment will give students the ability to empathize (Atasoy, 2006). When time spent in nature is supported by empathy and discovery and encouraged during appropriate and critical periods of child development, the bond established with nature can play a role as a source of social action (Sobel, 2014). Therefore, one of the best methods for developing children's empathy skills is to encourage children's relationships with both real and imaginary animals and plants (Sobel, 2014). The interests and attitudes that occur at an early age form the basis of the students' future behavior. In addition, value judgments, especially at an early age, help develop empathy between the child and nature and foster love for nature (Guergachi et al., 2010; Sobel, 2014; Tam, 2013). In addition, the development of children's cognitive, affective and psychomotor skills is supported in established relationships with animals and plants.

\section{References}

Artut, K. (2009). Sanat eğitimi kuramlart ve yöntemleri. An1 Yayınc1lık. Atasoy, E. (2006). Çevre için eğitim: Çocuk doğa etkileşimi. Ezgi Kitabevi. Broyles, I. (2011). Distributed cognitıon minicourse: an instructional intervention toimprove the effectiveness of one-day environmental education camps. (A Dissertation Presented in Partial Fulfillment of the Requirements for The Degree Doctor of Philosophy). Capella University, United States.

Carson, R. (2011). Sesiz bahar. (Ç. Güner, Çev.). Palme Yayıncılık. (Orijinal çalışma basım tarihi 1962).

Creswell, J. W. (2017). Araştırma deseni: Nitel, nicel ve karma yöntem yaklaşımları. (S. B. Demir, Çev. Ed.). Eğiten Kitap.

Cutter-Mackenzie, A. (2009). Multicultural school gardens: creating engaging garden spaces in learning about language, culture, and environment. Canadian Journal of Environmental Education, 14, 122-135. https://cjee.lakeheadu.ca/article/view/891 
Damerell, P. J. (2007). From knowledge to behaviour: can environmental education realise its potential? (Master Thesis). Imperial College London, London.

Danielraja, R. (2019). A study of environmental awareness of students at higher secondary level. Shanlax International Journal of Education, 7(3), 6-10. https://doi.org/10.34293/education.v7i3.480

Davis, J. (2009). Revealing the research 'hole' of early childhood education for sustainability: a preliminary survey of the literature.

Environmental Education Research, 15(2), 227-241.

https://doi.org/10.1080/13504620802710607

Egbonyi, E. E., \& Onnoghen, U. N. (2016). From environmental awareness to environmental responsibility: towards a stewardship curriculum.

Journal of Educational Issues, 2(2), 60-72.

http://dx.doi.org/10.5296/jei.v2i2.9265

Erol, G. H., \& Gezer, K. (2006). Prospective Primary school teachers' attitudes toward environment and environmental problems.

International Journal of Environmental and Science Education, 1(1), 65-77. http://www.ijese.net/makale/1261.html

Evans, G., Brauchle, G., Haq, A., Stecker, R., Wong, K., \& Shapiro, E. (2007). Young children's environmental attitudes and behaviors. Environment and Behavior, 39(5), 635-659.

https://doi.org/10.1177/0013916506294252

Frantz, C. M., \& Mayer, F. S. (2014). The importance of connection to nature in assessingenvironmentaleducation programs. Studies in Educational Evaluation, 41, 1-5. https://doi.org/10.1016/j.stueduc.2013.10.001

Gadenne, D. L., Kennedy, J., \& McKeiver, C. (2009). An empirical study of environmental awareness and practices in SMEs. Journal of Business Ethics, 84, 48. https://doi.org/10.1007/s10551-008-9672-9

Gal, H., \& Linchevski, L. (2010). To see or not to see: Analyzing difficulties in geometry from the perspective of visual perception. Educational Studies in Mathematics, 74, 163-183. https://doi.org/10.1007/s10649-010-9232-y

Glesne, C. (2013). Nitel araştırmaya giriş (Çev. Ed. Ersoy, A. ve Yalçınoğlu, P.). Anı Yayıncılık. 
Grodzinska-Jurczak, M., Stepska, A., Nieszpotek, K., \& Bryda, G. (2006). Perception of enviromental problems among preschool children in Poland. International Research in Geographical and Enviromental Education, 15(1), 62-76. https://doi.org/10.2167/irgee187.0

Guergachi, A., Ngenyama, O., Magness, V., \& Hakim, J. (2010). Empathy:

A unifying approach to address the dilemma of "environment versus economy'. In Paper presented at International congress on environmental modelling and software, 293.

https://scholarsarchive.byu.edu/iemssconference/2010/all/293/

Güler, A., Halıcıoğlu, B. H., \& Taşğın, S. (2014). Sosyal bilimlerde nitel araştırma. Seçkin Yayıncılık.

Güler, T. (2009). The effects of an ecology based environmental education on teachers' opinions about environmental education. Education and Science, 34(151), 30-43.

http://egitimvebilim.ted.org.tr/index.php/EB/article/viewFile/606/85

Hadzigeorgiou, Y., \& Skoumios, M. (2013). The development of environmental awareness through school science: Problems and possibilities. International Journal of Environmental \& Science Education, 8, 405-426. http://dx.doi.org/10.12973/ijese.2013.212a Hungerford, H. R., \& Volk, T. L. (1990). Changing learner behavior through environmental education. The Journal of Environmental Education, 21(3), 8-21.

https://doi.org/10.1080/00958964.1990.10753743

Johnson, B., \& Christensen, L. (2014). Eğitim araştırmaları (Çev Ed. Demir, S. B). Eğiten Kitap.

Krishnamurti, J. (2008). Ĕ̈itim üzerine (Çev. Arslanlığlu, S.). Ayna Yayınevi.

Krishnamurti, J. (2012). Doğa ve çevre üzerine. (3. Bask1). (N. Demirdöven ve D. Demirdöven, Cev.). Ayna Yayınevi.

Long, B. E. (2007). A study of enviromental education in Missouri: A survey of Project wet facilitators of enviromental education. (Unpublished PhD dissertation). University of Colombia-Missouri, USA.

Louv, R. (2012). Doğadaki son çocuk: çocuklarımızdaki doğa yoksunluğu ve doğanın sağaltıcı gücü. (C. Temürcü, Cev.). TÜBİTAK Popüler Bilim Kitaplar1. 
Mahidin, A. M. M., \& Maulan, S. (2010). Understanding children preferences of natural environment as a start for environmental sustainability. Procedia - Social and Behavioral Sciences, 38, 324 333. https://doi.org/10.1016/j.sbspro.2012.03.354

Meinhold, J. L., \& Malkus, A. J. (2005). Can knowledge, attitudes, and self-efficacy make a difference? Envıronment and Behavıor, 37(4), 511-532. https://doi.org/10.1177/0013916504269665

Merriam, S. B. (2014). Nitel araştırma desen ve uygulama için bir rehber. (Çev. Ed. Turan, S.). Nobel akademi yayıncılık.

Milton, B., Cleveland, E., \& Bennett-Gates, D. (1995). Changing perceptions of nature, self, and others: A report on a park/school program. Journal of Environmental Education, 26(3), 32-39. https://doi.org/10.1080/00958964.1995.9941443

Nagra, V. (2010). Environmental education awareness among school teachers. Environmentalist, 30, 153-162. https://doi.org/10.1007/s10669-010-9257-x

Özdemir-Balakoğlu, M. (2019). Sanat eğitiminde duygusal algl ve estetik. Aralık Kitap.

Öznacar, D. M., Turan Güllaç, E. \& Gülay, H. (2010). İlköğretim 4. 5. 6. 7. 8. sinıflar için güncel çevre sorunları ile ilgili eğitsel etkinlikler. Anı Yayınc1lik

Özsoy, S., \& Ahi, B. (2014) İlkokul öğrencilerinin geleceğe yönelik çevre algılarının çizdikleri resimler aracılığı ile belirlenmesi. Educational Sciences: Theory \& Practice, 14(4), 1557-1582. https://doi.org/10.12738/estp.2014.4.1706

Patton, M. Q. (2015). Nitel araştırma ve değerlendirme yöntemleri. (M. Bütün ve S. Beşir Demir. Çev. Ed.). Pegem Akademi Yayıncılık.

Rogayan, D., \& Nebrida, E. (2019). Environmental awareness and practices of science students: input for ecological management plan. International Electronic Journal of Environmental Education, 9(2), 106-119. https://dergipark.org.tr/en/pub/iejeegreen/issue/45317/481304

Said, A. M., Yahaya, N., \& Ahmadun, F. R. (2002). Environmental comprehension and participation of Malaysian secondary school students. Environmental Education Research, 13(1), 17-31. https://doi.org/10.1080/13504620601122616 
Seggie, F. N, \& Bayyurt, Y. (2015). Nitel araştırma, Anı Yayıncılık. Shepardson, D. P. (2005). Student ideas: What is an environment? The Journal of Environmental Education, 36(4) 49-58.

https://eric.ed.gov/?id=EJ725565\#: :text=In\%20general\%2C\%20stu dents $\% 20$ understood $\% 20$ an,as $\% 20$ environments $\% 20$ by $\% 20$ these $\% 2$ 0students.

Sobel, D. (2014). Ekofobiyi aşmak: Doğa ĕgitiminde kalbin yeri (İ. Urkun Kelso, Cev.). Yeni İnsan Yayınevi. (Orijinal çalışma basım tarihi 1996).

Sugg, P. G. (2008). Science and enviromental field experiences at a formal enviromental education site: an investigation of teacher participation and educators perception in a large urban school district.

(Unpublished $\mathrm{PhD}$. Dissertation). Texas A and M, USA.

Şimşekli, Y. (2004). Çevre bilincinin geliştirilmesine yönelik çevre eğitimi etkinliklerine ilköğretim okullarının duyarlılığ Eğitim Fakültesi Dergisi, 17(1), 83-92.

http://www.acarindex.com/dosyalar/makale/acarindex1423935676.pdf

Tam, K. P. (2013). Dispositional empathy with nature. Journal of Environmental Psychology, 35, 92-104. https://doi.org/10.1016/j.jenvp.2013.05.004

Uzun, N., Sağlam, N., \& Uzun, F. V. (2008). Yeşil sınıf modeline dayalı uygulamalı çevre eğitimi projesinin çevre bilinci ve kalıcılığına etkisi. Ege Ĕ̈itim Dergisi, 9(1), 59-74. https://www.pegem.net/dosyalar/dokuman/124969-2011090995031makale_4.pdf

Van Den Berg, A. E., Joye, Y. \& De Vries, S. (2015). Doğanın să̆lı̆̆a faydalart (L. K. Cicerali ve E. E. Cicerali, Cev.). L. Steg, A. E. Van Den Berg ve J. I. M. De Groot (Ed.), Çevre psikolojisi. Nobel Akademi Yayıncılik.

Vaughan, C., Gack, J., Solorazano, H., \& Ray, R. (2003). The effect of environmental education on schoolchildren, their parents, and community members: a study of lnteraenerational and 1ntercommunity learning. The Journal of Environmental Education, 34, 12-21. https://doi.org/10.1080/00958960309603489 
Waktola, D. K. (2009). Challenges and opportunities in mainstreaming environmental education into the curricula of teachers' colleges in Ethiopia. Environmental Education Research, 15(5), 589-605. https://doi.org/10.1080/13504620903151024

Walsh-Daneshmandi, A., \& MacLachlan, M. (2006). Toward effective evaluation of environmental education: validity of the children's environmental attitudes and knowledge scale using data from a sample of Irish adolescents. The Journal of Environmental Education, 37(2), 13-23. https://doi.org/10.3200/JOEE.37.2.13-23

Wells, R., \& Zeece, D. P. (2007). Books for children my place in my world literature for place-based environmental education. Early Childhood Education Journal, 35, 285-291. https://doi.org/10.1007/s10643-0070181-8

Wihardjo, S. D., Hartati, S., Nurani, Y., \& Sujarwanta, A. (2017). The effects of green schooling knowledge level and intensity of parental guidance on the environmental awareness of the early age student. Educational Research and Reviews, 12(5), 251-257. https://doi.org/10.5897/ERR2015.2608

Wilson, R. A. (1996). Environmental education programs for preschool children. Journal of Environmental Education, 27(4), 28-33. https://doi.org/10.1080/00958964.1996.9941473

Xuehua, Z. (2004). An Overview of the environmental knowledge system for primary school students. Chinese Education and Society, 37(4), 45-47. https://doi.org/10.1080/10611932.2004.11031654

Yavuzer, H. (2012). Çocuğu tanımak ve anlamak. Remzi Kitabevi.

Yener, D., \& Kalıpc1, E. (2007). A survey study on environmental knowledge of education faculty students. Journal of International Environmental Application and Science, 2(6), 71-78. https://dergipark.org.tr/tr/pub/jieas/issue/16165/168995

Yıldırım, A., \& Şimşek, H. (2016). Sosyal bilimlerde nitel araştırma yöntemleri. Seçkin Yayıncılık. 
Mustafa Yeşilyurt is Associate Professor, Yildiz Technical University, Faculty of Education, Department of Basic Education, Primary School Education, Istanbul, Turkey

Mukadder Özdemir Balakoğlu is Art Education Specialist, Yildiz Technical University, Faculty of Education, Department of Basic Education, Primary School Education, Istanbul, Turkey

Mustafa Erol is Research Assistant, Yildiz Technical University, Faculty of Education, Department of Basic Education, Primary School Education, Istanbul, Turkey

Contact Address: Mustafa Erol, Yildiz Technical University, Faculty of Education, Department of Basic Education, Primary School Education, İstanbul, Turkey. e-mail: merol@yildiz.edu.tr 